Tej Bahadur Chitrakar, Lord Shiva in Joyous Mood, 1962, Oil on canvas, $76 \mathrm{~cm} \times 56 \mathrm{~cm}$,

Collection of Madan Chitrakar, Kathmandu.
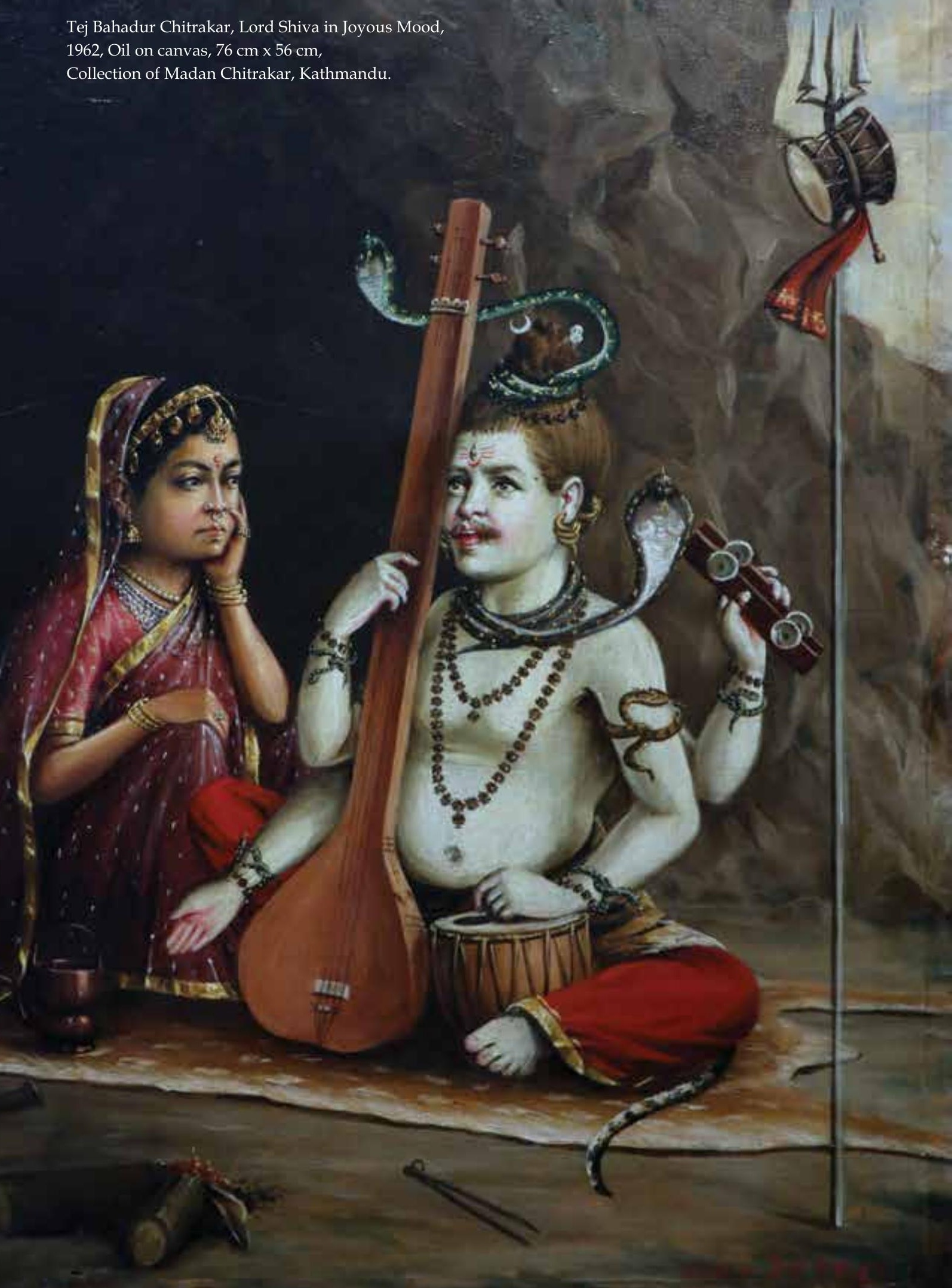


\title{
DEVELOPING TRENDS OF MUSIC IN THE VEDIC AND MYTHOLOGICAL ERAS
}

\author{
Dr. Ramesh Pokharel \\ Associate Professor \\ Campus-Chief, Lalitkala Campus, TU
}

\begin{abstract}
The Vedas are religious texts which inform the religion of Hinduism also known as Sanatan Dharma; meaning eternal order or eternal Path. The Vedic - mythological period is considered to be the golden era in the history of world literature. Not only did the philosophy of the age reach a new pinnacle; but even aspects of music, art, culture, literature, sculpture, religion, and spiritualism were extended to their highest point. Amongst these cultural instruments, Music represents vocal and instrumental sounds combined in such a way as to produce beauty of form, harmony and expression of emotions. During this era music - vocal and instrumental were held in high respect in society. Music had both ritual and secular aspects. Sämaveda is considered as the root of Vedic music as well as the root of today's south Asian classical music. Sämagāna was considered as the sound of inspiration for the people of that age. This paper attempts to discuss the musical situations in Vedic and Mythological periods regarding its origin, development, extension and practices in ancient south-eastern i.e. Hindu civilization. The paper also points out why the need and importance of Vedic music in present day society is much more; especially in regards to the adoption of lessons and ethics from Sanatan Hinduism.
\end{abstract}

\section{Keywords: Stuti-gāna, gāthā-gāna, Gram-murchhana, Sabda-Brhama-Naada, Om, Sāmagati}

\section{Introduction}

From the chanting of ancient Vedic hymns to the melodic bhajans of modern-day devotees, our music is deeply rooted with the basic spiritual principles of sacred sound. It is said that the time of Vedic Period extended from 4500 B. C. to 1000 B. C. The Vedas are the most primitive literary records of
Indo-Aryan civilizations. It mostly consists of mantras or prayers and summons in praise of various Gods. The word Veda means insight, facts, or revelation and it is valued and regarded as the language of Gods simplified to human speech. In pre-historic times, before the dawn of civilization, men used to express their feelings through different types of tunes and through 
movements of the body. Later on, in the Vedic period, music acquired a similar form. The saints of the time used to sing the hymns of the Vedas in a musical chant. Apart from this, music was common in different sacrificial ceremonies of the Aryans. Hymns from Sama-Veda were also sung at those functions. The use of music was, however, limited to performances at sacred places only (Khan, 1992, p.12). Sāmaveda is considered as the root of Vedic music. The people of that age tried to get strength and inspiration by performing the Sāmagāna. People of the Vedic era offered prayer to different deities in the form of Sāmagati. While in the Rigveda, the mantras were without song or melodies; in the Sāmaveda the mantras were connected with melodies and thus appeared as Sāmagāna. In each and every yajňa Sāmagāna was sung. Stuti-gāna and gāthā-gāna were also famous. Music was not only considered as the ritual performance, but often times it was also considered as a social activity. Hence, it is not worthy to say that during the Vedic era, the music only remained as a medium for entertainment, rather it appeared as the medium of Sādhanā which would lead to the ultimate and supreme realization.

\section{Materials and methods}

The study is based on secondary sources of data that has been collected from various sources like books, journals, and articles. Analysis of the information has been conducted through qualitative approaches.

\section{Origin and development of Vedic music}

The Vedic-Aryan era is considered to be the golden era in the history of world literature and Music. It was believed that waves of sound, considered as sabda-brahma, stays hidden in the sky. This sabda originates from the sky, stays in the sky and dissolves in the sky. And thus, after the emergence of sabda, the speech of all birds, animals, snakes, and even human beings flowed out from the sky. The ancient poets had the intellect to realize the presence and beauty of the natural forces and hence unified themselves with those forces and founded paramātmā. The basic element of musical structure is Naada. In eastern philosophy, Naada is the primary cause of the phenomenal world. Sound is considered to be the manifestation of Naada which is described as Naada-Brahma in the Shastra (Mahajan, 2001, p.37). The Origin of Music is "Naad" and origin of Naad is "Divine Pranav" i.e. Om. It is a musical sound and also a series of regular vibrations. The heart of the process of creation is believed to be Naada. In Hinduism, the sacred syllable Om embodies the essence of the universe. Naada Brahma is a primal word in ancient Indian spirituality, a primal word that also refers to the great classical music of the Indian subcontinent. As a matter of fact, most ancient time music in this continent has been practise as a spiritual science and art, and a means to enlightenment.

The music of Indian sub-continent is said to be one of the oldest unbroken musical traditions in the world. The history of the Indian subcontinent starts with the Indus Valley Civilization and the coming of Aryans; both are known as Pre-Vedic and Vedic periods (Mcintosh, 2008, p. $30-31)$. It is said that the origin of this system goes back to the Vedas. In Vedic period, music was used mainly for two functions: to propitiate deities and to 
accompany sacrificial offerings. Music formed an important part of the rituals which structured various sacrifices that formed the essence of the Vedic religion. In fact, singing, instrumental music and dance were described as divine in Vedic literature. It is said that Vedic period started after the arrival of Aryans who established the caste system in the society, such as the Brahmin (priestly class), Kshatriya (ruling and martial class), Vaishya (trading class), and Sudra (menial class). The Aryans were nomads who worshipped gods (their gods were all representation of nature). Their literature known as Rigveda has many hymns for the gods, and they distinguished between small gods and the Supreme Creator. Their worship includes sacrifice followed by the prayers. The Aryans expanded their empire first towards the valleys of the Ganges and the Jamuna and later to include the whole of the Northern Indian Subcontinent. The Rigveda is a collection of inspired songs or hymns and is the main source of information on the Rigvedic civilization. Brahmin people used to provide the knowledge of music to the remaining three castes. Musicians were characterized as bright and intelligent, and were honoured by people. The main feature of this period was the immense participation of women in music. They openly participated in singing, dance and especially in veena (string instrument) playing (Garg, 1999, p.15). Similarly, during this period, an Aswamedh yagya was organized where all the people participated by entertaining the music as well as performing group dances.

The Vedas were musically recited. Udatta (raised, sharp or acute), Anudatta (not raised, grave) and Swarita (acute, grave) were the three pitches used in Vedic recitation (Singh, 1995). Svara is how a syllable has to be pronounced in one of the three accents (udatta, anudatta, and svarita). Sama Vedic music was generally confined to three to five notes. The musical chanting of the Sama Veda employed more notes and finally settled on seven. It is said to be the source of the later secular and classical music. Though all the seven notes were isolated and recognized, in course of time through the Vedic period, the chanting always began with the sacred syllable 'Om.'

The important thing when stanzas of the Rigveda were a set to tones and tunes, they were called the Vedic Sama Gana. In fact, the word Sama itself is a compound expression and includes two entities: the first component 'Sa' refers to hymns, i.e. Richa, and the second component 'Ma' refers to the musical notes. The singing of Sama was accompanied by the veena in accordance with a procedure that connected body-movements, gestures and correct intonation in singing. Seated properly, the singer was to touch the middle phalanx of the fingers of the right palm with the right thumb according to the pitch of the note intended. A disciple learnt this procedure by imitating his preceptor in pitch, intonation as well as in finger movements (www.itcsra.org).

Tracing the evolution of formalized music, we find that Sama Vedic music was the initial formalized music that evolved out of folk music. The chanting of Sama Vedic music was melodic while Yajurveda chanting was rhythmic (Ramakrishna, 2003 p.15). The next step was Gandharva music as described in Bharata's Natyashastra. It adopted the 
Samvedic scales, Murchhna, Grama, etc. and created a new kind of musical system called Jatis. Thus, it is found that the Vedic music was the initiation of classical music in the subcontinent. Many of the features of music of this period permeated in various ways and in different proportions in different kinds of eastern music. The music of this time is the earliest example of the deep relationship between religion and music in the subcontinent.

\section{Mythological period}

The origin of music is attributed to gods and goddesses and to mythological figures like gandharvas and kinnaras who feature in the stories and practices of music. Music is an integral part of Hindu Mythology. Music in the spiritual world was practised by Gandharvas and demigods. Indra and other gods requested the Creator, Brahma to give the people something which not only creates a diversion from their bad ways but helps in their upliftment. Brahma agreed and gave music to people through Narada Muni (sage), a human with extraordinary abilities. Even now, Narada is represented on images carrying a Tanpura. In Puranas such as, Vayu, Vishnu and Markandeya as well as the Tantras, we get enough materials about Shruti, Swar, Murchhana and Grama. The term 'Gandharva' stands for music in the Purans and Tantras. The names Vashistha, Yajnyavalkya, Narada, Kashyapa and Panini are mentioned among the early musicologists.

Nandikeshwara is famous for his work on the structure of language as well as for the treatise 'Nandibharatam' or 'Bharatarnavam' on Music. In the Vayu Purana, the latter half of chapter 56 deals with Gandharvam (the art and science of Music) and chapter 57 is a treatise on Gitalankara (embellishments in Music). In the puranas there is a reference to bahirgitam which is the song sung in front of the stage before starting a dramatic performance. In the 21st chapter of Markandeya Purana, we find the myth of Saraswati giving the boon of music to the naagas. Here the details of 7 swaras, gramas, 7 gitikas, 7 Murchanas, 3 layas, 4 talas, 3 gatis, 4 kalaas and 49 tanas are found (Ramakrishna, 2003, p.4-5).

It is also unanimously acknowledged by all wise men that Brahma- the eternal supreme power is the creator of this Universe. Naturally the origin of Music starts from him. He imparted this heavenly art to Shiva, the God of eternal bliss. He delivered it to goddess Saraswati, the goddess of knowledge and wisdom, who taught this art to Narada and the heavenly musicians and dancers; namely Gandharvas, the Apsaras or the dancers of the heaven, and lastly the Kinnaras, the performers of musical instruments in the heaven. In this way from Lord Brahma to Shiva to Saraswati to Narada to Gandharva to Apsaras to Kinnaras are considered to be the great musicians in the Mythological Period. It is found in Hindu Mythology that the different aspects of life and learning were associated with different gods, goddesses and sages. So, it is natural that the mythologists might have ascribed the origin of the art of music and dance to some certain gods, goddesses and sages according to their self-style, ideas and realisation (Bandyopadhyaya, 2012, p. 9). In the epics of the Ramayana, Mahabharata, evidences are given of the values attached to systematized classical music. There are descriptions of various musical instruments like 
Bheri, Dundubhi, Ghat, Dim Dim Banshi, Adamber and Sankha etc. are found in these famous epics. These texts inform about Lord Shiva, Brahma, Saraswati, Narad, Tamburu, Lav-Kush, Krishna and Arjun, Brihannala who were great musicians. According to the Ramayana, all classes of people were delighted in Fine Arts. Sages were also skilled in Gandharva tattva (science of music). Professional music maestros or Acharyas were experts in music. Their performances were arranged in Raja Sabhas or Courts for the elite. In these epics, we find the picture of the places named Ayodhya and Janakpur which were vibrant with the sound of veena, mridanga, banshi, sankh, damaru etc. Characters like Rama and Sita, Sugriva, and even Ravana were fond of music and dance. Kings of different kingdoms used to wake up from their slumber to the tune of music every morning. Lava and Kusha, the sons of Ram also were taught music by Sage Valmiki who was known to be a skilled musician. In the Virata Parva (the episode of Pandavas in hiding) of the Mahabharata, Arjun is seen as a music and dance teacher in the guise of Brihannala or eunuch at the Royal Palace of King Birat. In Bhagavat Purana, Lord Krishna is seen as a great musician who always holds a flute in his hand and entertains his associates. The musical Rasa Leela Dance of Krishna who is known as Rasaraja or the king of rasa enjoys music and dance with his male and female associates. These stories are still popular today in present day Hindu culture.

\section{Conclusion}

In the earliest days during the Vedic era, the melodies were taught only by oral repetition or by playing them in instruments. At the time of singing, notes were marked nicely by the priests by the movement of their hands and fingers. From all the discussions and analysis conducted, it can definitely be said that the Sāmaveda Sa $\square$ hitā is certainly valuable to the history of today's South Asian concept of sacrifice and charm; and its gānas were certainly very important during the Vedic period as well as for the development of today's eastern and world music. The origin of music is attributed to Gods and Goddesses and to mythological figures like gandharvas and kinnaras who are a character in all the stories and practices of music. It can safely be concluded that music was fully developed during the Vedic and Mythological periods. The practice of music in ancient society was well organized through a Sama-Vedic way of Vedic mantra presentation.

\section{References}

Bandyopadhyaya, S. (2012). Indian Music through the Ages: 2400 BC to the Present Era. Delhi: B. R. Rhythms.

Garg, B. (1999). Sangeet Visharad (23 ${ }^{\text {rd }}$ ed.). Hathras, India: Sangeet Karyalaya, Hathras.

Khan, M. H. (1992). Islamic Contribution to South Asia's Classical Music. New Delhi: Sterling Publishers, Pvt. Ltd.

Mahajan, A. (2001). Ragas in Hindustani Music: Conceptual Aspects. New Delhi: Gyan Publishing House.

Mcintosh, J. R. (2008). Understanding Ancient Civilization: The Ancient Indus Valley, New Perspectives. USA: ABC - CLIO, Inc.

Pal, S. (2017). Significant Role of Music in the Vedic Age. International Journal of Sanskrit Research 3(5): 51-56. www.anantaajournal.com

Ramakrishna, L. (2003). Musical Heritage of India. New Delhi: Shubhi Publication.

Singh, T. J. (1995). Indian Music. Calcutta: Sangeet Reasearch Academy.

(www.itcsra.org). 